\title{
THE MOTILITY OF THE SMALL INTESTINE IN SPRUE ${ }^{1}$
}

\author{
BY FRANZ J. INGELFINGER AND ROBERT E. MOSS \\ (From the Evans Memorial, Massachusetts Memorial Hospitals, and the Department of \\ Medicine, Boston University School of Medicine, Boston)
}

(Received for publication November 25, 1942)

An abnormal small-intestinal pattern has been demonstrated by roentgenologic studies in both the tropical and non-tropical variety of sprue (1 to 3 ). Generalized hypomotility is observed, and the barium moves along the gut in thick, sausageshaped masses which are separated by intestinal areas, apparently in a state of spasm. Many of the bowel loops are widely dilated and often contain considerable gas. At the same time, the mucosal relief is strikingly altered in that the usual markings of the valvulae conniventes are thickened, widely separated, and, in advanced cases, completely obliterated. In an admirable review of this subject, Golden (4) has, however, reiterated the original contention of Snell and Camp (1) that the observed changes are not characteristic of sprue, but may occur in other chronic deficiency states and, at times, may appear as the result of emotional stresses.

In 2 patients with sprue, whom we repeatedly intubated over a period of 8 and 13 months, respectively, the small-intestinal motor activity was studied by means of the balloon-kymograph method, described by Ingelfinger and Abbott (5). Of the 2 patients, the first would be considered to have the tropical, the second, the non-tropical variety of sprue.

\section{CASE REPORTS}

Case 1. W. C., a 36-year-old man, first noticed loose stools at the age of 21 , shortly after he had been purser for 6 months on a boat sailing between New York and South America. Since that time, he had suffered from intermittent bouts of weight loss, distension, cramps, and frequent bowel movements, consisting of light stools never containing blood or pus. In the year before entry to this hospital, he had been subjected to 3 ileostomies in an effort to relieve his distension and cramps.

Physical examination on July 18 , 1941, revealed an emaciated individual with extreme hypotonia of the entire musculature. A brown pigmentation covered the forehead, cheilosis was present, and the tongue appeared dark red and smooth. The abdomen was markedly distended and tympanitic. Both a proximal and a distal ileostomy

1 This study was supported in part by a grant from Brewer \& Company, Inc., Worcester, Massachusetts. opened onto the abdominal wall, which was severely irritated by the constant discharge of intestinal contents. The skin of the legs appeared slightly scaly.

A biopsy of a mesenteric lymph node and of smallintestinal tissue, taken when the ileostomies were closed, revealed evidences of chronic inflammation and a brown pigment (hemofuscin), diffusely deposited throughout the intestinal musculature as well as the lymphoid tissue.

Case 2. W. J., a 45-year-old man of Portuguese descent, was discovered to have a severe macrocytic anemia and hypocalcemic tetany, 4 years before entry. Although he experienced fatigue and weight loss, his bowel movements were to the best of his knowledge rarely abnormal. He had always lived in northern latitudes. Physical examination on admission revealed a fairly well-developed man with flaring of the costal margins, markedly protruding abdomen, and "clubbing" of the fingers. Tympanites was not striking.

Results of significant laboratory studies in both these cases are listed in Table I.

\section{RESULTS}

When the record obtained from the jejunum of a patient with sprue is compared with a normal jejunal record, striking and consistent differences are noted (Figure 1). Whereas the normal upper small intestine prevents the standard balloon from filling with more than 10 to $30 \mathrm{cc}$. of air under pressures averaging $20 \mathrm{~cm}$. of water, the gut in sprue offers much less resistance to increases in the volume of the balloon, even when the pressures in the balloon system are below $10 \mathrm{~cm}$. of water. In our 2 cases, this lack of intestinal resistance to distension was roughly proportional to the severity of the disease. Thus, in Case 1 , a pressure of 5 to $9 \mathrm{~cm}$. of water was at times sufficient to inflate the balloon with $75 \mathrm{cc}$. of air. When the standard balloon contains this much air, an error is introduced by the fact that some of the resistance to distension is effected by the elasticity of the balloon itself; but this error does not invalidate the results, since it tends to decrease rather than increase the balloon volume. In Case 2, where the patient had less severe manifestations of sprue, $45 \mathrm{cc}$. of air was maintained in the balloon by a pressure of 10 to $15 \mathrm{~cm}$. of water. 
TABLE I

Results of significant laboratory studies in 2 patients with sprue

\begin{tabular}{|c|c|c|}
\hline & Case 1 & Case 2 \\
\hline $\begin{array}{l}\text { Hematological studies: } \\
\text { Red blood count (millions) } \\
\text { Hemoglobin (grams) } \\
\text { Hematocrit (per cent) } \\
\text { Mean corpuscular volume (c. } \mu \text { ) } \\
\text { Mean corpuscular hemoglobin }(\boldsymbol{\gamma} \gamma) \\
\text { Mean corpuscular hemoglobin concentration (per cent) } \\
\text { Reticulocytes (per cent) } \\
\text { White blood count }\end{array}$ & $\begin{array}{r}2.92 \\
10.8 \\
34.8 \\
119.0 \\
37.3 \\
31.3 \\
1.5 \\
5,000.0\end{array}$ & $\begin{array}{r}3.11 \\
10.1 \\
33.8 \\
109.0 \\
32.8 \\
30.2 \\
1.9 \\
8,000.0\end{array}$ \\
\hline $\begin{array}{l}\text { Stools: } \\
\text { Gross appearance } \\
\text { Guaiac test } \\
\text { Culture }\end{array}$ & $\begin{array}{c}\text { Yellow, unformed } \\
1+ \\
\text { Parasaccharomyces A }\end{array}$ & $\begin{array}{l}\text { Gray, formed } \\
\qquad \begin{array}{l}\text { No monilia or } \\
\text { pathogenic organisms }\end{array}\end{array}$ \\
\hline $\begin{array}{l}\text { Fat content } \\
\text { Per cent of dried feces } \\
\text { Per cent of intake }\end{array}$ & $\begin{array}{l}56.0 \\
80.0\end{array}$ & $\begin{array}{l}49.0 \\
20.0\end{array}$ \\
\hline $\begin{array}{l}\text { Blood chemistry: } \\
\text { Total protein (grams per } 100 \mathrm{cc} \text { ) } \\
\text { Albumin (grams per } 100 \mathrm{cc} \text { ) } \\
\text { Globulin (grams per } 100 \mathrm{cc} \text { ) } \\
\text { Calcium (mgm. per } 100 \mathrm{cc} . \text { ) } \\
\text { Phosphorus (mgm. per } 100 \mathrm{cc} \text { ) } \\
\text { Cholesterol (mgm. per } 100 \mathrm{cc} \text { ) } \\
\text { Cholesterol esters (mgm. per } 100 \mathrm{cc} \text {.) } \\
\text { Carotenoids (mgm. per } 100 \mathrm{cc} \text { ) } \\
\text { Sodium (milliequivalents) } \\
\text { Prothrombin time (per cent of normal) } \\
\text { Phosphatase (King-Armstrong units) }\end{array}$ & $\begin{array}{c}5.4 \\
4.6 \\
0.8 \\
8.0 \\
2.0 \\
65.0 \\
50.0 \\
\text { less than } 0.02 \\
140.0 \\
30.0 \\
5.0\end{array}$ & $\begin{array}{c}7.1 \\
3.8 \\
3.3 \\
7.3 \\
2.7 \\
125.0 \\
90.0 \\
\text { less than } 0.02 \\
138.0 \\
60.0 \\
10.0\end{array}$ \\
\hline $\begin{array}{l}\text { Glucose tolerance test: } \\
\text { Fasting level (mgm. per } 100 \mathrm{cc} \text {.) } \\
\text { Peak rise (mgm. per } 100 \mathrm{cc} .)\end{array}$ & $\begin{array}{r}84.0 \\
111.0\end{array}$ & $\begin{array}{r}110.0 \\
90.0\end{array}$ \\
\hline $\begin{array}{l}\text { Vitamin A absorption: } \\
\text { Fasting level (I.U. per } 100 \text { cc. of plasma) } \\
\text { Peak rise }\end{array}$ & $\begin{array}{l}70.0 \\
76.0\end{array}$ & $\begin{array}{l}41.0 \\
53.0\end{array}$ \\
\hline $\begin{array}{l}\text { Pancreatic enzymes in duodenal juices after stimulation with } \\
\text { Amylase (Agren and Lagerlof) } \\
\text { Lipase (Crandall and Cherry) }\end{array}$ & $\begin{array}{r}560.0 \\
18,230.0\end{array}$ & $\begin{array}{r}322.0 \\
22,560.0\end{array}$ \\
\hline
\end{tabular}

The record of the normal upper small bowel is characterized by large (L) waves and small (S) waves, which may occur independently or may be superimposed. At the time that our patients were first studied, no spontaneous $\mathrm{L}$ waves were observed in Case 1 during 504 minutes of recording; and none in Case 2 during 57 minutes of recording. The $\mathrm{S}$ waves, while present and of a frequency lying within the normal range of 8 to 12 per minute, produced smaller excursions than are usually seen.

Although the most striking changes were observed in the jejunum, the records of duodenal and ileal activity in our patients showed similar deviations from normal.
The rate at which the balloon and tube were moved along the small intestine was only slightly slower than normal and occurred even during the period when $\mathrm{L}$ waves were not present.

\section{RESULTS OF THERAPY}

In our advanced case of sprue (Case 1), therapy affected the small-intestinal motor activity but slightly. No change at all was brought about by the daily parenteral administration of $30 \mathrm{mgm}$. of thiamin hydrochloride for 11 days or by the daily ingestion of 1.5 grams of choline hydrochloride for 1 week. Parenteral vitamin B complex and liver extract (see Table II) produced no improvement in the appearance of the intestinal 


\section{RECORDS OF JEJUNAL ACTIVITY}

NORMAL

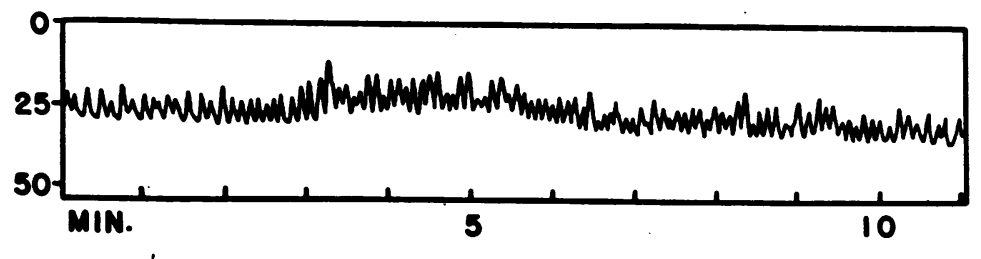

SPRUE W. C.

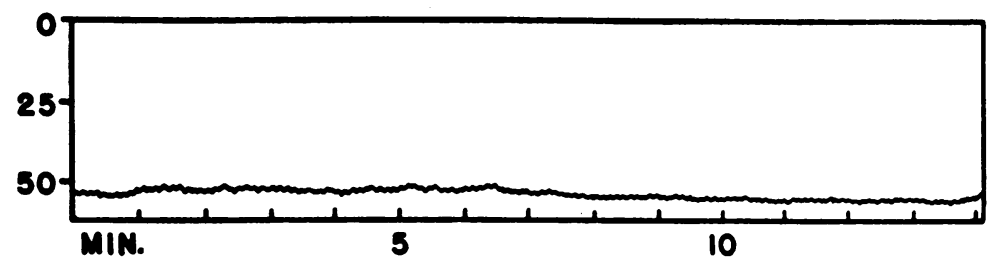

SPRUE W. J.

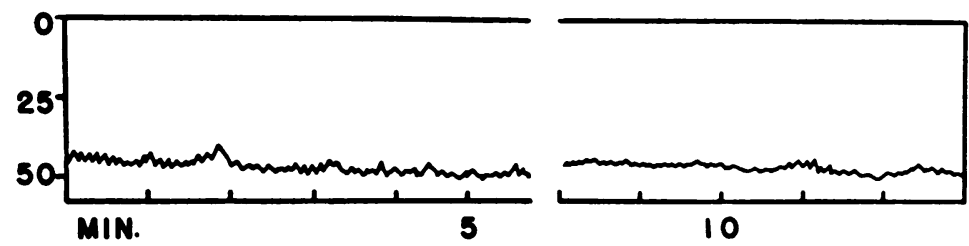

Fig. 1. Comparison of the Records of Jejunal Activity in a Normal Subject and in 2 Patients with Sprue

TABLE II

Vitamin medication given to 2 patients with sprue

\begin{tabular}{|c|c|c|c|c|c|c|c|c|c|}
\hline & $\begin{array}{c}\text { July 18, } \\
1941 \text { to } \\
\text { August 12, } \\
\text { 1941 }\end{array}$ & $\begin{array}{l}\text { August 12, } \\
1941 \text { to } \\
\text { Ootober 3, } \\
1941\end{array}$ & $\begin{array}{c}\text { Ootober } 4, \\
1941 \text { to } \\
\text { Oetober } 15 \\
1841\end{array}$ & $\begin{array}{l}\text { Oetober 16, } \\
1941 \text { to } \\
\text { November 12, } \\
1941\end{array}$ & $\begin{array}{l}\text { November 13, } \\
1941 \text { to } \\
\text { December } 20, \\
1941\end{array}$ & $\begin{array}{l}\text { December 20, } \\
1941 \text { to } \\
\text { January } 12, \\
1942\end{array}$ & $\begin{array}{l}\text { January 13, } \\
1042 \text { to } \\
\text { May 1, } 1942\end{array}$ & $\begin{array}{l}\text { May 1, } 1942 \\
\text { to } \\
\text { June 2, } 1942\end{array}$ & $\begin{array}{c}\text { June 2, } 1942 \\
\text { to } \\
\text { Auguat 1, } 1942\end{array}$ \\
\hline $\begin{array}{l}\text { Thismin hydrochloride (mgm.) } \\
\text { Niootinic acid (mgm.) } \\
\text { Liver extract (USP unito) }\end{array}$ & $\begin{array}{c}15,000 \\
2,500 \\
75 \\
1 \mathrm{i} . \mathrm{m} . \\
10 \mathrm{i} . \mathrm{m} . \\
300 \\
0\end{array}$ & $\begin{array}{r}30,000 \\
5,000 \\
75 \\
1 \text { i.m. } \\
6 \\
300 \\
8 \\
(2 \text { re. trice a } \\
\text { peed for } 13\end{array}$ & $\begin{array}{c}15,000 \\
2,500 \\
75 \\
1 \\
(t+100 \mathrm{a} \\
\text { reok, i.m.) } \\
30 \mathrm{im} . \\
300 \\
0\end{array}$ & $\begin{array}{c}15,000 \\
2,000 \\
75 \\
1 \\
\text { (trice a } \\
\text { reet, im.) } \\
0 \\
0 \\
0\end{array}$ & $\begin{array}{c}15,000 \\
2,500 \\
75 \\
1 \\
\text { (trico a } \\
\text { weck, i.m.) } \\
0 \\
0 \\
5 \\
\text { (5 ce. i.m.) }\end{array}$ & $\begin{array}{c}50,000 \text { i.m. } \\
5,000 \\
75 \\
1 \\
\text { (per week, } \\
\text { L.m.) } \\
0 \\
0 \\
2 \frac{1}{\xi} \\
\text { (21 oc. i.m.) }\end{array}$ & $\begin{array}{c}30,000 \\
5,000 \\
75 \\
1 \\
\text { (per week, } \\
\text { i.m.) } \\
0 \\
0 \\
21 \\
\text { (2) ce. I.m.) }\end{array}$ & $\begin{array}{c}15,000 \\
2,500 \\
50 \\
1 \\
\text { (per } 2 \text { weeks, } \\
\text { i.m.) } \\
0 \\
0 \\
2 \frac{3}{3} \\
\left(2 \frac{1}{2} \text { co. im.) }\right.\end{array}$ & $\begin{array}{c}30,000 \\
5,000 \\
50 \\
1 \\
\text { (per woek, } \\
\text { im. }) \\
0 \\
60 \\
21 \\
(21 \text { oc. } 2 \text { times } \\
\text { a woek ism.) }\end{array}$ \\
\hline $\begin{array}{l}\text { Brewcis yeast (grams) } \\
\text { Ribofiavin (mgm.) } \\
\text { B complex "(cc.) }\end{array}$ & $\begin{array}{l}\mathbf{2 . 5} \\
\mathbf{0} \\
\mathbf{0}\end{array}$ & $\begin{array}{l}\mathbf{0} \\
\mathbf{5} \\
\mathbf{0}\end{array}$ & $\begin{array}{l}\mathbf{0} \\
\mathbf{5} \\
\mathbf{0}\end{array}$ & $\begin{array}{l}0 \\
0 \\
5 \text { i.m. }\end{array}$ & $\begin{array}{l}0 \\
0 \\
\text { sim.m. }\end{array}$ & $\begin{array}{l}0 \\
0 \\
21 \mathrm{im} .\end{array}$ & $\begin{array}{l}0 \\
0 \\
21 \mathrm{i} . \mathrm{m} .\end{array}$ & $\begin{array}{l}0 \\
0 \\
21 \mathrm{im} .\end{array}$ & $\begin{array}{l}\mathbf{0} \\
\mathbf{3} \\
\mathbf{0}\end{array}$ \\
\hline
\end{tabular}

Vitamin medication, Case W. C. Unless otherwise noted daily and oral dosages are recorded.

* Said to contain $3 \mathrm{mgm}$. thiamin hydrochloride, $10 \mathrm{mgm}$. nicotinic acid amide, $0.5 \mathrm{mgm}$. riboflavin, $0.450 \mathrm{mgm}$. pyridoxine, and $1.680 \mathrm{mgm}$. pantothenic acid per cc.

\begin{tabular}{|c|c|c|c|c|c|}
\hline & $\begin{array}{l}\text { January 21, } 1942 \text { to } \\
\text { Pebruary 4, } 1942\end{array}$ & $\begin{array}{l}\text { February 4, } 1942 \text { to } \\
\text { February 27, } 1942\end{array}$ & $\begin{array}{l}\text { February 27, } 1942 \text { to } \\
\text { March 17, } 1942\end{array}$ & $\begin{array}{c}\text { March 17, } 1942 \text { to } \\
\text { April 4, } 1942\end{array}$ & $\begin{array}{l}\text { April 4, } 1942 \text { to } \\
\text { July } 1,1942\end{array}$ \\
\hline $\begin{array}{l}\text { Brower's yeast (grams) } \\
\text { Vitamin D (USP unita) } \\
\text { Vitamin } \mathbf{K} \text { (mgm.) (oral preparation) } \\
\text { Liver ertract (USP units) } \\
\text { Vitamin A (USP units) }\end{array}$ & $\begin{array}{r}0 \\
4,000^{*} \\
0 \\
0 \\
0\end{array}$ & $\begin{array}{r}50 \\
4,000^{*} \\
15^{*} \\
0 \\
0\end{array}$ & 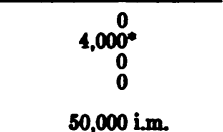 & $\begin{array}{r}5,000 \\
0 \\
0 \\
30,000\end{array}$ & $\begin{array}{c}0 \\
6,000 \\
0 \\
4 \text { to } 8 \\
(1 \text { to } 2 \text { co.) every } 2 \text { days } t \\
30,000\end{array}$ \\
\hline
\end{tabular}

Vitamin medication, Case W. J. Unless otherwise noted, daily and oral dosages are recorded.

* The preparations used were said to be water-soluble. † The patient was not regular in obtaining this medication. 


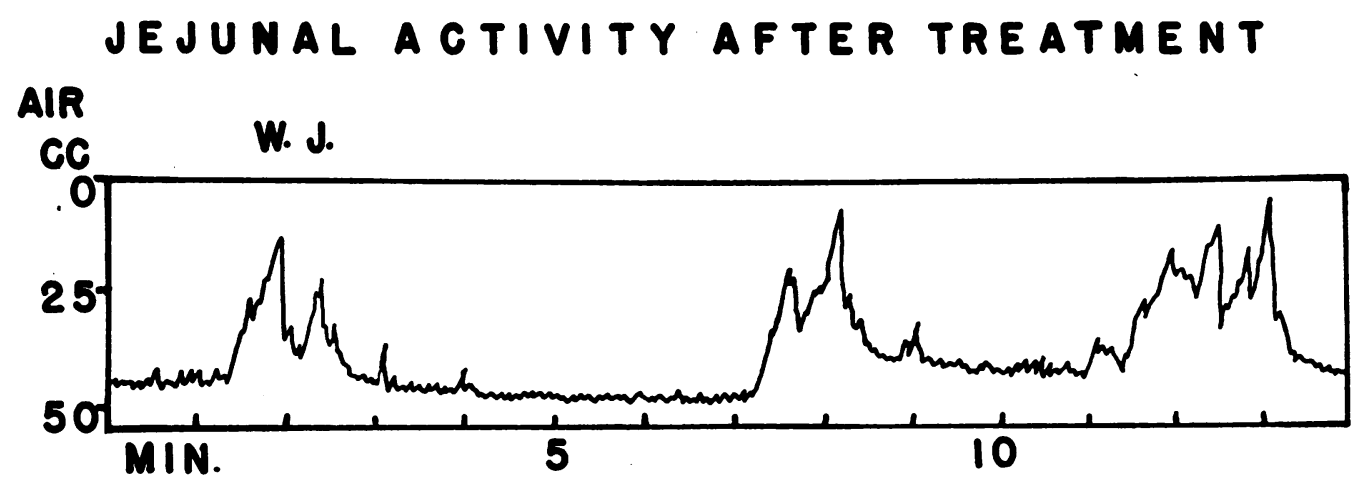

W. C.

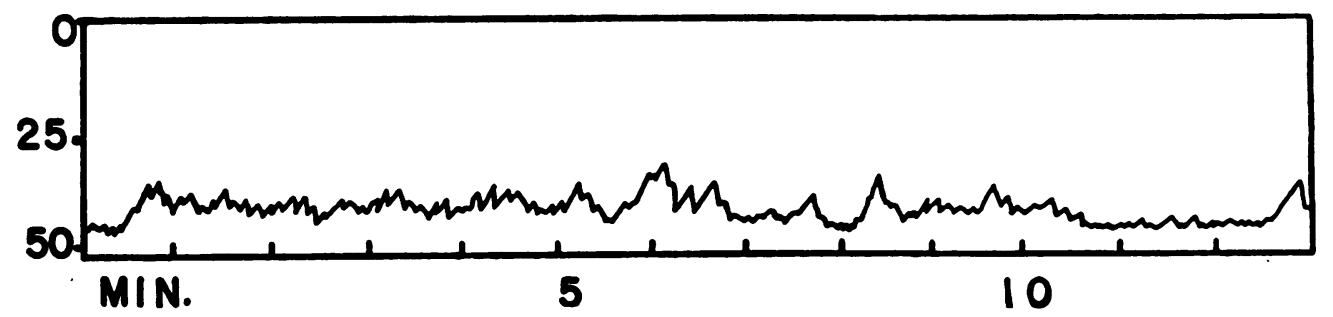

Fig. 2. Records of Jejunal Motor Activity in 2 Patients with Sprue After Treatment with Parenteral Liver Extract and Vitamin B Complex

records during the early months of treatment; but after 8 months, a slight but definite return toward normal was recorded in the duodenum and high jejunum (Figure 2). The mid-jejunum, however, continued to show the same abnormalities which were exhibited before therapy was begun. Although the effects of therapy on intestinal motility were not remarkable, the clinical results were striking in that the patient gained 60 pounds, and the stomatitis, distension, cramps, and diarrhea abated almost completely.

In Case 2, treatment with 50 grams of Brewer's yeast daily for $3 \frac{1}{2}$ weeks resulted in no change in the intestinal record. A record taken after the patient had received 2 to $4 \mathrm{cc}$. of liver extract every other day for 12 weeks showed striking $\mathrm{L}$ waves (Figure 2), which in this instance were associated with rapid advance of the balloon.

\section{EFFECT OF OHANGING PRESSURES IN THE BALLOON (IN C M. OF WATER)}
$15 \mathrm{CM}$
$4 \mathrm{CM}$.
$8 \mathrm{CM}$.
5 CM.
$20 \mathrm{CM}$.

AIR

C.C.

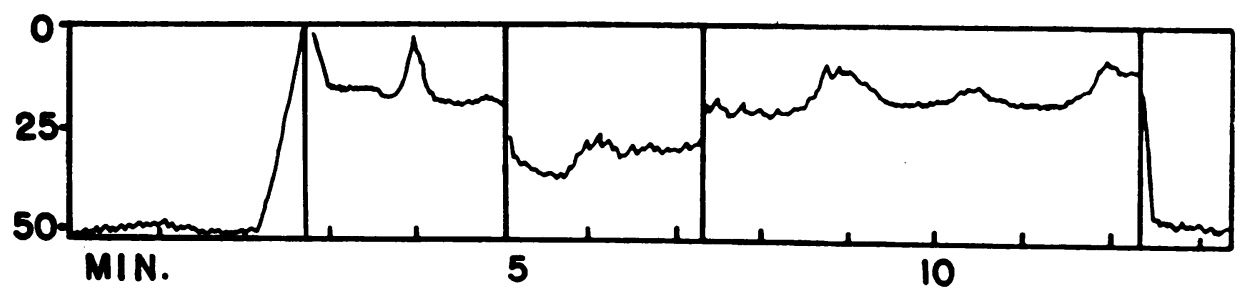

Fig. 3. Demonstration That the Small. Intestine in Sprue Compresses Our Standard Balloon ( 50 cc. capacity) When It Contains Only 15 cc. of Air, Provided the Pressure Within THE Balloon Is SMall 
EFFECTS OF VARYING THE PRESSURES IN THE BALLOON SYSTEM

The pressures usually maintained in the balloon system (10 to $20 \mathrm{~cm}$. of water) were reduced in order to determine whether the gut in severe sprue is in a constant state of relaxation, or whether the intestinal lumen can decrease in diameter if the intra-balloon pressures are minimal. As Figure 3 shows, a ballon inflated under a pressure of $5 \mathrm{~cm}$. of water and containing only $15 \mathrm{cc}$. of air will occasionally be compressed by the intestinal activity. At other times, however, only respiratory movements can be recorded under similar conditions.

\section{EFFECTS OF DRUGS}

The effects of prostigmine $(0.5 \mathrm{mgm}$. subcutaneously), posterior-pituitary solution (20 units subcutaneously), and acetyl-beta-methylcholine chloride (10 mgm. subcutaneously) in Case 1 are shown in Figure 4. Each of these drugs was used twice and the results can be summarized by saying that acetyl-beta-methylcholine stimulated, whereas prostigmine and posterior-pituitary solution did not affect the motor activity of the small intestine. The posterior-pituitary solution was, however, most effective in promoting the expulsion of gas and material from the large bowel, whose continuity with the small gut had been interrupted by an ileostomy. Desoxycorticosterone $(5 \mathrm{mgm}$. intramuscularly on each of 3 consecutive days) produced no change in the small-intestinal motor activity, nor did $10 \mathrm{cc}$. of an aqueous extract of the adrenal cortex when given intramuscularly on each of 2 days.

In Case 2, prostigmine ( $0.5 \mathrm{mgm}$. subcutaneously) changed the control record only slightly, whereas acetyl-beta-methylcholine $(10 \mathrm{mgm}$. subcutaneously) reduced the average balloon volume from 47 to $35 \mathrm{cc}$. In effecting this increase in the intestinal resistance to distension by the balloon,

\section{EFFECT OF SOL. POST. PITUITARY I GG (20 UNITS) S. G.}

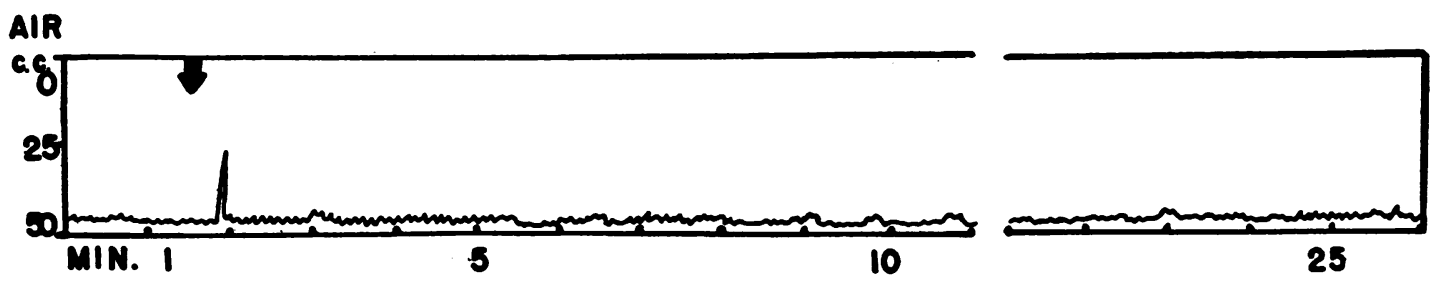

EFFECT OF ACETYL BETA METHYLCHOLINE 10 MG. S. C.

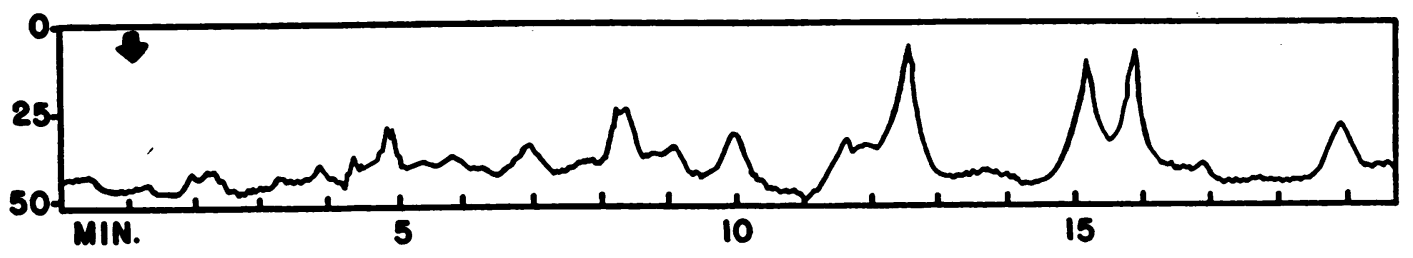

EFFECT OF PROSTIGMIN 0.5 MG. S. C.

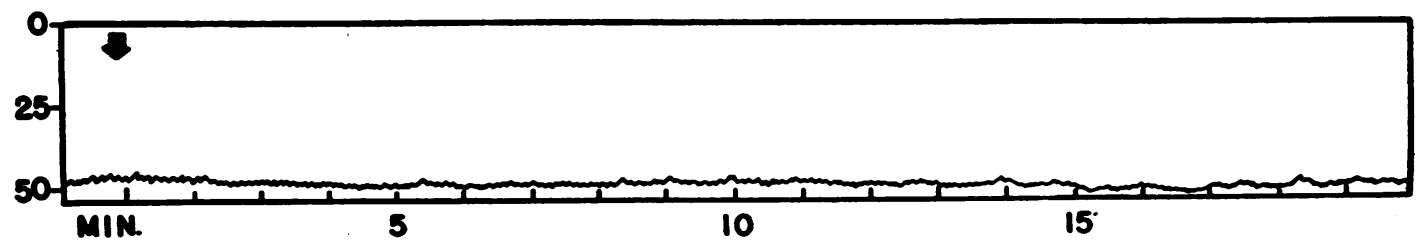

Fig. 4. Effect of Drugs on the Small-Intestinal Motor Activity in a Severe Case of Sprue 
acetyl-beta-methylcholine produced an almost normal intestinal record for a period of 28 minutes.

In both patients, the effects of acetyl-beta-methylcholine on the intestinal record appeared 1 to 2 minutes after other effects of the drug, but persisted for 15 to 20 minutes after the profuse sweating and general feeling of discomfort had subsided.

\section{DISCUSSION}

Balloon records of intestinal motor activity are of significance only if correctly used and interpreted with due regard to the limitations of the method. There may be some question whether the presence of any balloon and tube in the intestines is physiologic; but if the diameter of the distended balloon exceeds the usual diameter of the gut, or if the balloon system produces intestinal obstruction by being anchored in one area-errors which are often encountered in the literature-the records can certainly not be considered indicative of normal intestinal activity. Further errors may be introduced by using large balloons in an organ of irregular outlines (such as the stomach), where a symmetrical balloon may at one time be affected by the actual intraluminal pressure of the organ, while at other times it is compressed by the walls of the hollow viscus. Furthermore, as Quigley and his associates (6) have pointed out, the large balloons usually employed, whether elastic or of relatively fixed volume, do not measure intraluminal pressure, but merely indicate intestinal activity by changes in the volume or the pressure within the balloon.

In our experiments, we have used an elastic balloon which can accommodate itself to changes in the intestinal lumen. This balloon is kept as closely as possible to a standard size so that it contains $50 \mathrm{cc}$. when filled, but not distended, with air. In this state, its diameter measures $3.5 \mathrm{~cm}$. The balloon is inflated by pressures ranging usually from 10 to $20 \mathrm{~cm}$. of water. These pressures are within the range of normal intra-intestinal pressures $(6,7)$. The balloon and attached tube are allowed to advance in accordance with intestinal activity by keeping plenty of slack in the stomach. Fluoroscopy is used to check the position of the tube.

The small-intestinal records obtained by this method show that the volume of the balloon in 2 patients with sprue is 2 to 3 times greater than when the balloon is inflated under similar pressures in the normal gut. The intestine in sprue can then be considered to lack tone, in the sense that the normal resistance to distension by intestinal contents is greatly diminished. This lack of tone is, so far as can be told from observation on only 2 cases, roughly proportional to the clinical severity of the disease.

The configuration of the $\mathrm{S}$ and $\mathrm{L}$ waves in the normal small intestine roughly corresponds to the Type I and Type II waves described in the human colon by Adler, Atkinson, and Ivy (8), although the frequency of the small waves in the small bowel appears to be greater than that in the colon. In our patients with sprue, L waves were conspicuously absent for long periods of time. When the balloons were inflated under slight pressures, however, or after stimulation with Mecholyl, or after a period of treatment, $L$ waves were recorded. We may thus assume that $\mathrm{L}$ waves can occur in sprue under certain conditions, although their appearance is intermittent, and the intervals between their appearance may be lengthy. Since the $\mathrm{L}$ waves are most effective in advancing the balloon system and the intestinal contents trapped behind it, their intermittent appearance in a bowel lacking tone may account for the sausage-like clumping of barium sulfate observed in roentgenological studies of the bowel in sprue.

The $S$ waves appear to occur in sprue as in the normal gut. Although comparable to the Type I waves seen in the colon, we do not believe that the $S$ waves can be called non-propulsive, for the balloon can advance in the intestine even when $\mathrm{L}$ waves are not observed, and, as has been noted $(5,9)$, the $S$ waves in the small intestine appear to travel down the gut.

Pendergrass and his associates (10) found that the roentgenologic appearance of the small intestine was altered by an olive-oil meal to such an extent that the pattern might be mistaken for that seen in steatorrhea. This finding led Snell (11) to suggest that possibly malabsorption of fat is the sole responsible factor in the production of the roentgenologic changes seen in sprue. So far as our records are concerned, however, this possibility can be dismissed, since our tracings were taken in intestinal segments empty of all food residues. Preliminary observations in sub- 
jects with no gastrointestinal disease have also shown that the intra-enteric injection of olive oil may alter some of the motor activity of the small bowel, but never to the extent that the resultant changes might be confused with sprue.

Our records show that therapy with vitamins, particularly the $\mathrm{B}$ complex, may be followed by marked clinical improvement without correspondingly great changes toward normal in the tracings of intestinal motility. This observation differs from the roentgenologic findings of Snell (11) and of Miller and Rhoads (12), who noted marked improvement in the appearance of the small intestine after 4 days of treatment with liver extract, but it corresponds to the experience of Golden (4), who "has not seen this [that is, a complete return to normal] happen in a case of well-developed steatorrhea." In all likelihood, both the degree and the duration of the patient's illness determine whether or not therapy will be effective in restoring intestinal motor activity to normal.

In the normal small intestine, prostigmine increases the intestinal tone (as defined previously) and the frequency of the $\mathrm{L}$ waves (13). In our patients with sprue, prostigmine had little effect. Acetyl-beta-methylcholine chloride, on the other hand, appeared to stimulate intestinal motility in sprue as it does in normal individuals (14). Prostigmine is said to exert its cholinergic effect by inhibiting the choline esterase which normally destroys acetylcholine, whereas acetyl-beta-methylcholine chloride acts directly on the effector cells, as does acetylcholine (15). In view of these facts, our observations suggest that the primary defect in sprue is the inability of the intestinal autonomic nervous system to liberate acetylcholine. This hypothesis would explain the ineffectiveness of prostigmine, for the inhibition of choline esterase would increase intestinal motility only if acetylcholine were being produced. It is also consistent with the damage to the intramural nerve cells which Golden (4) has described.

A posterior-pituitary preparation (pitressin) was found by Elsom, Glenn, and Drossner (16) to increase the intestinal motor activity, particularly peristalsis. This effect was more pronounced in the more distal portion of the gut. Until the action of principles from the posteriorpituitary preparation upon the intestines is more fully understood, we cannot make any deductions from the fact that these principles failed to affect the small gut of 1 patient with severe sprue.

\section{SUM MARY}

Records of the small-intestinal motor activity were repeatedly taken in 2 patients with sprue.

These records show that the gut in sprue lacks the usual resistance to distension exhibited by the normal intestine, that $\mathrm{L}$ waves are only intermittently present, and that $S$ waves tend to be of small amplitude.

Treatment over short periods of time with individual fractions of the vitamin B complex produced little change in the tracings. Prolonged treatment with whole vitamin B complex produced some improvement in the records, but this improvement was not commensurate with the clinical results obtained.

Injections of acetyl-beta-methylcholine chloride stimulated the intestinal motility in our patients, but prostigmine was without effect. In 1 patient, posterior-pituitary solution, adrenal-cortical extract, and desoxycorticosterone produced no changes. These observations suggest that in sprue the nervous apparatus of the small intestine fails to liberate active acetylcholine.

\section{BIBLIOGRAPHY}

1. Snell, A. M., and Camp, J. D., Chronic idiopathic steatorrhea: roentgenologic observations. Arch. Int. Med., 1934, 53, 615.

2. Mackie, T. T., Miller, D. K., and Rhoads, C. P., Sprue: roentgenologic changes in the small intestine. Am. J. Trop. Med., 1935, 15, 571.

3. Kantor, J. L., The roentgen diagnosis of idiopathic steatorrhea and allied conditions. Am. J. Roentgenol., 1939, 41, 758.

4. Golden, R., Abnormalities of the small intestine in nutritional disturbances: some observations on their physiologic basis. Radiology, 1941, 36, 262.

5. Ingelfinger, F. J., and Abbott, W. O., Intubation studies of the human small intestine. XX. The diagnostic significance of motor disturbances. Am. J. Digest Dis., 1940, 7, 468.

6. Brody, D. A., Werle, J. M., Meschan, I., and Quigley, J. P., Intralumen pressures of the digestive tract, especially the pyloric region. Am. J. Physiol., 1940, 130, 791.

7. Abbott, W. O., Hartline, H. K., Hervey, J. P., Ingelfinger, F. J., Rawson, A. J., and Zetzel, L., The clinical significance of gastro-intestinal pressure changes. J. Clin. Invest., 1940, 19, 768. 
8. Adler, H. F., Atkinson, A. J., and Ivy, A. C., A study of the motility of the human colon: an explanation of dysynergia of the colon, or of the "unstable colon.” Am. J. Digest. Dis., 1941, 8, 197.

9. Ingelfinger, F. J., and Moss, R. E., The activity of the descending duodenum during nausea. Am. J. Physiol., 1942, 136, 561.

10. Pendergrass, E. P., Ravdin, I. S., Johnston, C. G., and Hodes, P. J., Studies of the small intestine. II. The effect of foods and various pathologic states on the gastric emptying and the small intestinal pattern. Radiology, 1936, 26, 651.

11. Snell, A. M., Tropical and non-tropical sprue (chronic idiopathic steatorrhea) : their probable interrelationship. Ann. Int. Med., 1939, 12, 1632.

12. Miller, D. K., and Rhoads, C. P., The effect of liver extract on the small intestine of patients with sprue. Am. J. M. Sc., 1936, 191, 453.

13. Unpublished observations.

14. Abbott, W. O., Acetyl-beta-methylcholin. II. The action on the gastro-intestinal tract of normal persons, in abdominal distension, and in certain other conditions. Am. J. M. Sc., 1933, 186, 323.

15. Goodman, L., and Gilman, A., The Pharmacological Basis of Therapeutics. The Macmillan Company, New York, 1941.

16. Elsom, K. A., Glenn, P. M., and Drossner, J. L., Intubation studies of the human small intestine. XVIII. The effect of pitressin and of amphetamine (benzedrine) sulfate on the motor activity of the small intestine and colon. Am. J. Digest. Dis., 1939, 6, 593. 